\title{
LA SIRENA EN DOS RELATOS ORALES ANDINOS Y AMAZÓNICOS
}

\author{
THE MERMAID IN TWO ANDEAN AND AMAZONIAN ORAL \\ STORIES
}

\section{A SEREIA EM DUAS HISTÓRIAS ORAIS ANDINAS E AMAZÔNICAS}

\author{
Manuel Cornejo Chaparro* \\ Centro Amazónico de Antropología y Aplicación Práctica (CAAAP) \\ Miembro del Equipo de investigación EILA-UNMSM \\ mcornejo@caaap.org.pe \\ ORCID: 0000-0002-5242-1793
}

Recibido: $25 / 02 / 21$

Aceptado: $11 / 03 / 21$

* Investigador del Centro Amazónico de Antropología y Aplicación Práctica (CAAAP) y miembro del Equipo de investigación EILA-UNMSM. Ha publicado diversos artículos sobre literatura, antropologia, historia y arte amazónico en revistas especializadas. En 2009 publicó, con Alberto Chirif, el libro Imaginario e imágenes de la época del caucho: Los sucesos del Putumayo (CAAAP-IWGIA-UCP). En 2011 editó con Jean Pierre Chaumeil y Oscar Espinosa el libro Por donde hay soplo, Estudios Amazónicos en los Países Andinos (IFEA-PUCP-CAAAP), en 2013 conjuntamente con Alberto Chirif y Juan de la Serna publicó el Álbum de fotografías de la Comisión Consular al Rio Putumayo y Afluentes 1912 (AECID-CAAAP-Tierra Nueva-IWGIA), en 2015 publicó Los pueblos achuar, awajún, kandozi y wampis (Ministerio de Cultura), en 2019 coordinó con Juan Carlos La Serna la revista Ama-

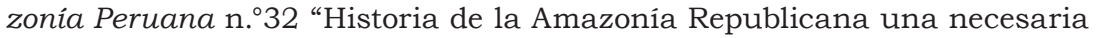
reflexión bicentenaria”. 


\section{Resumen}

En este artículo analizaremos dos relatos sobre la sirena en contextos culturales andinos y amazónicos. Pondremos énfasis tanto en sus similitudes y diferencias discursivas. A través del análisis de estos relatos proponemos una interacción cultural entre las sociedades andinas y amazónicas y esbozar algunas nociones sobre el proceso dinámico de las literaturas orales.

Palabras Clave: Andes, Amazonía, literaturas orales, sirenas.

\section{Abstract}

In this article we will analyze two stories about the mermaid in Andean and Amazonian cultural contexts. We will emphasize both their discursive similarities and differences. Through the analysis of these stories, we propose a cultural interaction between the Andean and Amazonian societies and outline some notions about the dynamic process of oral literatures.

Keywords: Andes, Amazonia, oral literatures, mermaids.

\section{Resumo}

Neste artigo analisaremos duas histórias sobre a sereia nos contextos culturais andino e amazônico. Enfatizaremos suas semelhanças e diferenças discursivas. Por meio da análise dessas histórias, propomos uma interação cultural entre as sociedades andina e amazônica e delineamos algumas noções sobre o processo dinâmico das literaturas orais.

Palavras-chave: Andes, Amazonas, literaturas orais, sereias.

\section{Introducción: o cómo abrir trocha}

La relación de los relatos orales entre la región andina y el espacio amazónico es un trabajo que recién está germinando, aunque en 1923 Julio C. Tello mencionó la relación existente entre ambas regiones ${ }^{1}$, no dio motivo a que exista el interés de elaborar investigaciones comparativas entre estos dos espacios culturales. Más bien, con el encumbramiento del "descubrimiento" de Machu Picchu por Hiram Bingham, se sentaron los cimien- 
tos de la nación peruana desde el pasado lítico y el esplendor del imperio de los Incas.

Esta "reconstitución narrativa" se vio fortalecida por una corriente de intelectuales que en la década de los 20, como Valcárcel, elaboraron una "antigüedad inmemorial en los Andes a partir del registro de la relación entrañable y milenaria entre el hombre y la tierra" (López Lenci 2004, p. 258).

Esta corriente intelectual hegemónica, devenida después en el lustroso indigenismo, se vio potenciada en esa década y en las siguientes por figuras descollantes de nuestra aldea letrada, como José María Arguedas, Luis Valcárcel, Gamaliel Churata, José Sabogal, Julia Codesido, por citar algunos.

Es entonces que la Amazonía es desplazada de nuestro imaginario intelectual y pasa a ser un espacio cultural de segundo orden, limitando su valor simbólico a contextos socio-políticos o de tensión fronteriza, en que la sociedad peruana miraba cada cierto tiempo hacia la Amazonía, en un afán de incansable y amnésico descubrimiento, que revestía, sin ninguna duda, un sinfín de préstamos y herencias coloniales ${ }^{3}$.

Pero también existió una narrativa contrahegemónica. En ese sentido, tenemos que resaltar la labor pionera del escritor Francisco Izquierdo Ríos, quien escribió el libro de relatos "Ande y Selva" en 1939. Este libro refleja las interacciones discursivas y elementos comunes en el imaginario popular de ambas regiones. El libro de Izquierdo Ríos denota aquella frontera inventada y esas historias fragmentadas y complementarias que transitan ambos lados de la cordillera.

Es recién en las últimas décadas que se han visto estudios - sobre todo desde la arqueología, la etnohistoria y la antropología- donde convergen las cosmovisiones de estas dos áreas geográficas y culturales. En 1985, Ortiz Rescaniere analiza comparativamente los relatos andinos de Wa-kón y Achiké con el relato awajún Ajaimpi y el Niño Sol. ¿Qué une a estos personajes? Los tres son dioses derrotados y habitan en el mun- 
do subterráneo, de cuevas oscuras y lejos del sol (Ortiz Rescaniere 1985, p. 81-82). Unos años después, Rostorowski (1992) menciona la presencia del Mito de Pachacamac en los actuales relatos orales de los pueblos Asháninka y Matsiguenka de la Amazonía. Con estos relatos orales - recopilados por Varese y Renard-Casevitz - se denota la presencia de estos pueblos amazónicos no solo en las interacciones culturales y económicas de esa época ${ }^{3}$, sino también el dinamismo y la vigencia de la oralidad de estos pueblos amazónicos. La vigencia de estas narraciones orales en el área amazónica puede ayudarnos a entender de manera más certera la sincronía de las sociedades andinas y amazónicas antes de la llegada de los españoles.

Pero no son solo las narraciones orales sino los espacios simbólicos que unen a las culturas andinas y amazónicas. El antropólogo Richard Chase Smith encontró 35 espacios territoriales vinculados a personajes y seres ancestrales, vigentes en la memoria oral yanesha ${ }^{4}$ ubicados en las zonas altoandinas y costeras de Lima. Según este autor, estos rastros orales aunados a descubrimiento arqueológicos e investigaciones lingüísticas nos hacen ver que el "espacio histórico-cultural yanesha" se encuentra en ambas vertientes de los Andes, desde el bosque amazónico hasta los valles de Lima (2011, p. 238).

Pero este no es el único ejemplo de interacción entre sociedades amazónicas y andinas. En un sugerente artículo, Jean Pierre Chaumeil señala con precisión que:

La tradición académica, sobre la cual vino a agregarse una serie de prejuicios de corte evolucionista, no hizo más que reforzar la separación entre ambas zonas, recurriendo a menudo a una visión pasadista y fosilizada de las sociedades amazónicas — a la par de una visión idealizada del mundo andino - visión que perdura hasta el dia de hoy. (2011, p. 295)

Chaumeil explora la relación entre los quipus andinos con los quipus (cuerdas anudadas) usadas en espacios rituales en 
distintas regiones de la Amazonía. Este autor se detiene en el caso del pueblo Yagua (Loreto) para ver de qué manera se utiliza este artefacto mnemotécnico en algunos ciclos rituales como la fiesta de iniciación masculina, en la entonación de cantos de fiestas comunales y cantos de guerra (2011, pp. 298-312).

Otro trabajo importante y sugerente para explorar estas interacciones culturales entre Andes y Amazonía es el artículo de Jaime Regan ${ }^{5}$ que compara ya no artefactos o indaga en la inscripción de la memoria oral amazónica en el paisaje andino y costeño, sino que compara unas imágenes de la iconografía mochica con algunos mitos jíbaros. Regan señala que a través de la arqueología se ha detectado contactos entre mochicas y jibaros. Este autor enfatiza que desde la tradición oral jibara se podría tener un mayor acercamiento a la historia mochica y las imágenes mochicas podrían ayudarnos a entender a las actuales sociedades jibaras (2011a, p. 267).

Desde los estudios literarios, la compilación de Gonzalo Espino (2003) Tradición oral, culturas peruanas - una invitación al debate - es un estudio fundacional porque no se limita al estudio de la tradición oral andina, sino que indaga en otros espacios culturales como el afroperuano y el amazónico. De esta manera, se pueden establecer esas interacciones discursivas que comentamos líneas arriba.

Finalmente debemos señalar la importancia del reciente trabajo de Godenzzi y Beauclair para relacionar ambos mundos orales. Aunque no llega a hacer un análisis comparativo de relatos que se desarrollan en ambos espacios culturales, los autores elaboran un marco histórico del desarrollo de los estudios orales de ambas zonas y presentan las principales investigaciones que vienen desde la Colonia hasta la actualidad ${ }^{6}$. Estos autores señalan que:

Los textos de la literatura oral andina y amazónica nos confrontan, a través de relatos y canciones, con los grandes problemas de la supervivencia, convivencia y condición 
humana, así como de la cohabitación entre humanos y la multiplicidad de seres no humanos: jaguares, anacondas, zorros; astros, estrellas, constelaciones; bosques, ríos, chacras; montañas tutelares, divinidades, etcétera. Pero además de confrontarnos con esos problemas, esos textos dan testimonio de la manera en que una comunidad, en un tiempo y lugar particular, ha sabido responder a esos desafíos. (2017, pp. 423-424)

La relevancia de presentar a las literaturas orales andinas y amazónicas en un solo estudio, denota la importancia de futuras investigaciones que analicen comparativamente estos relatos. Esta es la trocha a seguir.

\section{La sirena como constructo europeo-andino}

En un interesante artículo, la historiadora Isabel Revilla propone una relectura de algunos seres pisciformes que están presentes en el mundo acuático andino desde siglos antes. La autora sugiere que esos personajes que se encuentran en elementos arquitectónicos y en la artesanía de la región y suelen ser asociados a las sirenas, no constituyen un mero objeto de la tradición europea, sino que también tienen raíces andinas, las cuales no han sido registradas en la escritura totalmente (2012, p. 134). Aquí nos viene una primera interrogante: aunque no están inscritos en la escritura ¿Se podrá encontrar rasgos de estos seres en los actuales relatos orales andinos?

Revilla, a inicios del siglo XVII, basada en registros de Ludovico Bertonio afirma que "nos permite considerar una narración mítica de base local sobre Quesintuu y Umantuu"7. La autora propone establecer algunas pautas y estrategias de empoderamiento identitario para explicar la manera en que se originan y consolidan estos saberes ancestrales y se fijan y luego se resemantizan esta memorias locales (2012, p. 134) Esta conjunción de saberes y de marcas sincréticas en el espacio andino, podría ser también un ejemplo de los nuevos espacios 
culturales que se dan en las llamadas zonas de contacto donde dos universos culturales se juntan (Pratt, 2010) pero aquí habría que añadir la capacidad de lo que denominaremos agentes de contacto, es decir, aquellos elementos culturales que inician una suerte de lucha simbólica, enmarcada en el sincretismo cultural, pero luego van cimentando una narrativa propia, con elementos originales y foráneos que se van articulando y con ello prevalece la oralidad y religiosidad andina arropada en un bagaje occidental.

La autora señala a partir de las imágenes escultóricas en los templos andinos, así como de las imágenes de la sirena en la crónica de Guamán Poma, la diferencia de las sirenas andinas con las europeas. La primera es la dualidad (¿será un rastro de las deidades locales?). Lo segundo es la sensualidad y aspectos marcados de belleza (2012, p. 147). A partir de los trabajos de Gisbert, Revilla muestra la expansión de la figura de la sirena en los artefactos culturales y artísticos de la época colonial, desde keros, textiles, lienzos, grabados. Planteamos que la presencia de la sirena, además de estos elementos mencionados por la autora, también se inscriben y resemantizan en el espacio oral, en la palabra de los antiguos y en la memoria colectiva. Los relatos de la sirena en el espacio andino van resiginificándose en una dinámica de cambio; la voluptuosidad y sensualidad acarreada de peligro y desdestabilización del orden social, conlleva a una lucha de saberes y la predominancia del espacio social como refugio y sostén de la armonía con el medio natural y los embates de los agentes externos.

Teresa Gisbert llama la atención sobre la obra de Fernando Valverde, un religioso agustino, proveniente de una acaudalada familia limeña que visitó Copacabana en 1636. La obra consta de "16 silvas desarrolladas en 294 folios y está concebida como una nueva Odisea" (2012, p. 137).

En la obra de Valverde se pueden apreciar divinidades andinas. Los dioses de los puquinas, ancestrales pobladores del entorno lacustre altoandino, cuya naturaleza es acuática y sub- 
terránea, en contraposición a los dioses incaicos, vinculados al espacio celestial como el sol y el viento (Gisbert 2012, p. 152).

Valverde describe de esta manera a la sirena:

En este pues, infausto premontorio en hondas grutas, y espantosos senos se encastilló la furia más cruenta, que abortó de la Estigia el territorio:

Poderosa Sirena,

Que encanta vida con su misma pena, Venus la llama el mundo...

En estos versos, como afirma Gisbert, se puede apreciar el ídolo Copacabana, al parecer considerado femenino, que por sus rasgos acuáticos era considerada como sirena que vivía en la roca sagrada del Titicaca. La autora señala además la relación de esta sirena con Venus, vinculada al desvarío y goce carnal (2012, p. 152).

Pero además podemos ver cómo se inserta el imaginario griego en el altiplano, el espacio acuático es visto como un lugar tenebroso, oscuro, donde la sirena es considerada un aborto de la Estigia (personaje griego asociado al agua).

El poeta enuncia además la humanización del paisaje. Unido a las grutas, donde habitan las antiguas deidades andinas, menciona "los espantosos senos". Es decir, esta imagen de la sirena produce el horror, por eso el peligro de la empresa católica en el territorio altiplánico.

Esta imagen de la sirena ha transitado los siglos, se ha resemantizado y en ella se puede apreciar una suerte de resistencia cultural andina ${ }^{8}$. Ella evoca las deidades andinas. Gamaliel Churata asocia la sirena al pez de oro (el khori chalwa) o príncipe suchi en su obra más conocida (Mancosu 2013, p. 113) y los músicos andinos continúan la costumbre de dejar sus charangos para que se "sireneen" o se afinen a las orillas de los lagos 
y ríos, como se aprecia en las imágenes de Guamán Poma. Pero la sirena no solo se queda en los Andes sino cruza la cordillera hacia la Amazonía, como veremos a continuación.

\section{La sirena como constructo europeo-amazónico}

En las cosmovisiones amazónicas, la sirena pertenece al mundo de los Yacuruna (gente del agua). Estos seres tienen dos representaciones: una es la conocida, una mujer bella con cola de pez que atrae a los ribereños que andan solos por las orillas de los ríos; la segunda representación es la de una mujer con cola de serpiente. Por este motivo, está asociada a la Yacumama (la madre o espíritu o dueña del agua) (Regan 2011b, p. 149). De esta manera, podemos observar también esa conjunción de tradiciones originarias y europeas en la construcción simbólica de este personaje mítico que ha transitado el imaginario selvático durante siglos.

La sirena amazónica se adorna el cabello con sardinas y palometa (símbolo de la fecundidad) y sale del agua a seducir a los hombres para llevarlos a vivir con los Yacuruna que habitan en el fondo de los ríos, "su hamaca es la boa y su banco es la charapa, los bufeos negros son los músicos, la gorra del Yacuruna es la raya, sus zapatos son la carachama" (Regan 2011b, p. 147). En las cosmovisiones amazónicas un espíritu puede contener distintas convenciones corporales. Los espíritus no son "rigurosamente entidades taxonómicas" sino una serie de nominaciones relacionales, factuales y dinámicas. Por ende, todos los seres animados de la selva son "modulaciones intensivas" (Viveiros de Castro, 2007).

Este autor enfatiza que:

La evidencia etnográfica disponible sugiere que las cosmologias amerindias no tienen un concepto general, colectivo de "animal" opuesto a "humano". Los humanos son una especie entre otras, y a veces las diferencias internas a la humanidad van de la par con las diferencias entre especies... 
De ser esto verdad, entonces, por lo menos un sentido básico entre Naturaleza y Cultura debe ser descartado cuando nos movemos en contextos amazónicos. (2007, p.95)

De esta manera, los atributos físicos de la sirena los podemos entender desde la concepción amazónica como algo natural, donde el hombre es solo un ser más en este diálogo múltiple y diverso donde no existe distinción alguna entre los diferentes espacios corporales, oníricos, transformadores y cotidianos.

Por otro lado, tenemos la construcción mítica de este personaje en el contexto amazónico. Este espacio por constituir un escenario inédito y extraño produjo en los primeros cronistas no solo esa sensación de temor y maravilla ante tantas imágenes que perturbaron no solo sus conceptos y saberes, sino que tuvieron que rebuscar o encontrar nuevas palabras ante tan imponente paisaje y culturas.

La Amazonía entonces constituye el territorio ideal donde se pueden resignificar a los seres míticos griegos y medievales. Su mismo nombre devela el aspecto mítico en que se ha visto envuelto y que ha llegado hasta nuestros días. Un espacio fabulado, mitico, que ha dado lugar a leyendas que han transitado crónicas, novelas y películas.

Pero ¿cómo se elabora esta imaginación fabulosa y mítica sobre el territorio amazónico?

Ana Pizarro sostiene que existen cuatro elementos que posibilitan esta representación:

La significación de viaje y su preámbulo en las cortes europeas, el contexto medieval inquisitorial, la imaginería renacentista emergente, así como el interés que despiertan los escritos sobre viajes (2009, p. 56).

Estas narraciones sobre la Amazonía como un paraíso perdido, pero a la vez un lugar dantesco, caótico, poblado de seres extraños propició por un lado que estas imágenes y discursos se instalen en el pensamiento occidental, pero a su vez propi- 
cien las diferentes conquistas (militares, científicas, civiles) que han ansiado y convertido este territorio: como decía Mariátegui, en un espacio colonial, ya no solo interno, sino atemporal.

A continuación presentaremos dos relatos de la sirena, uno andino y el otro amazónico.

Hemos escogido estos relatos porque nos permiten apreciar estas interacciones culturales en ambos espacios culturales y porque los narradores del relato aparecen como autores (aunque sabemos que es complejo hablar de autoría en las narraciones orales), pero lo interesante es que estos narradores ya no figuran como simples informantes. Otro aspecto que unen a estos autores es el uso de imágenes elaboradas por ellos mismos que acompañan y dialogan con el relato.

\section{SIRENAS I}

\section{Carmelón Berrocal}

Dicen que una vez dos muchachos iban desde su pueblo a las punas. Iban a trabajar, pero también estaban buscando chicas bonitas para conversar. Caminando, caminando 1legaron cerca a la laguna de Plato Qocha. Como eran las doce del dia, se pusieron a descansar y comenzaron a comer sus fiambres.

Cuando estaban comiendo escucharon que los patos gritaban desde laguna. Uno de ellos miro hacia la laguna y vio con sorpresa que dos chicas bonitas de cabellos rubios estaban bañándose.

Pasó la voz al otro muchacho.

_ ¡Mira esas chicas bonitas en la laguna! 
El otro muchacho vio a las chicas y, entusiasmado, comenzó a silbarlas. Cuando las chicas de la laguna escucharon el silbido del muchacho, salieron muy rápido asustadas del agua y, desnudas, corrieron a buscar sus ropas.

4

- Vamos a conversar con esas chicas- dijo uno de los muchachos.

-No, dijo el otro. Esas muchachas no son verdaderas gentes humanas. Son sirenas. No vayas- pero su amigo no le hizo caso y se puso a conversar con las muchachas sin creer que fueran sirenas. Hasta le parecían conocidas y parecidas a otras amigas suyas.

Así fue que, conversando, conversando, el muchacho empezó a enamorarse de las chicas. Las muchachas empezaron a tocar su guitarra para distraer al muchacho. También cantaban. El muchacho las escuchaba y las miraba enamorado de ellas.

\section{6}

Dicen que los tres en la orilla de la laguna de Plato Qocha tocaron y cantaron hasta el atardecer. Cuando ya estaba cayendo el sol, empezaron a subir juntos.

El muchacho preguntó a las chicas:

- ¿Dónde viven?

Las chicas respondieron:

-Allá arriba, en la punta del cerro, allí vivimos.

Asi es que los tres juntos caminaron, subiendo el cerro hasta que amaneció. 


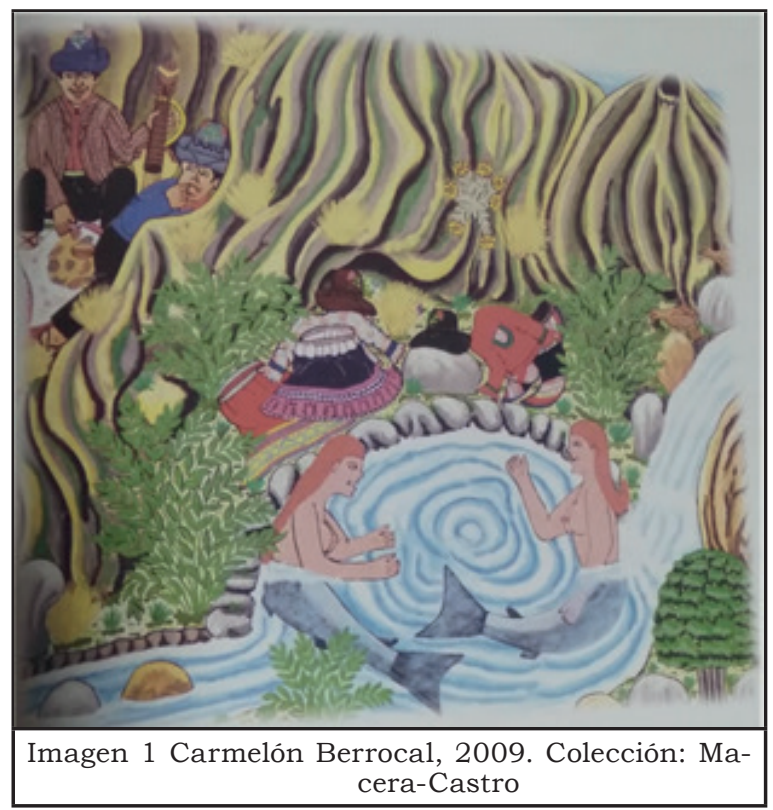

7

Una de las chicas le dijo al muchacho:

-Quédate con nosotras. Vamos a hacer una fiesta con mis primos y primas.

Como ya era de noche, el muchacho aceptó. La chica hizo entrar al muchacho a una casa muy linda y le presentó a sus primos y primas. Entre todos empezaron una fiesta con arpa, guitarra y un violín. Bailaban muy alegres. El muchacho estaba encantado. Había una gran mesa con frutas, papas, naranjas, plátanos y uvas.

8

-Estas gentes son buenas

- pensaba el muchacho- y estas chicas son muy bonitas con su cabello rubio - asi enamorado bailaba y bailaba con todas las muchachas como si fuera un sueño. 
De puro cansado, el muchacho, el muchacho se quedó dormido y, al día siguiente cuando despertó en la mañanita, vio que estaba en la puerta de una cueva. Al costado estaba sobre un helecho y sudando de frío. Entonces, el muchacho comprendió que sus amigas eras sirenas. Bajo rápido del cerro y nunca más volvió por alli.

Como señala Landeo, la sirena "pertenece a los seres imaginarios propiamente dichos al campo semántico de Seres del Agua. Su hábitat son las fuentes, ríos y lagunas solitarias y aparecen preferentemente al atardecer y en las noches de luna" (2010, p.230). Esto lo notamos en la primera secuencia del relato en que los dos jóvenes - que expresan el yanantin- llegan a la laguna.

En la segunda secuencia aparecen las dos chicas bonitas - con ecos de la dualidad de las divinidades andinas del agua-; las jóvenes del relato ya denotan una belleza física, pero con un énfasis en la alteridad al notarse sus cabelleras rubias. En la tercera secuencia vemos la "naturalización" de la comunicación. El joven silba para llamarlas, como un ave enamoradiza.

En la cuarta secuencia vemos una ruptura del yanantin de los jóvenes. Uno de ellos reconoce que son sirenas (es aquel que no uso el lenguaje naturalizado) y deja solo al amigo, Es ahí donde parece ocurrir la escena atemporal y la relación entre las diferentes multirealidades andinas. En el relato se recoge esta constante en la tradición andina, (a diferencia de la amazónica) que generalmente son jóvenes, solteros y solitarios; quienes alejados de su comunidad se encuentran con la sirena. Es importante señalar cómo aquel joven que silba (podemos clasificarlo como una melodía) siente a las sirenas cercanas y parecidas a unas amigas suyas. 
En la quinta secuencia notamos el tropo del canto y la música como elemento de atracción hacia las otras realidades. Como aparecen en la icnografía andina, tanto en las pinturas como en las esculturas en los pórticos de las iglesias y casonas, las dos sirenas mediante la música atraen al joven hacia su mundo y provocan su alejamiento de su ayllu, de su entorno familiar.

En la sexta secuencia se aprecia el espacio temporal que menciona Landeo:

Estos encuentros (tinkuy) ocurren en un tiempo denominado "mala hora", momento en que "muere" (wañun) el sol; en la transición de un tiempo de luz punchaw (dia) hacia tuta (oscuridad, noche) (2010, p.201).

A la hora del atardecer, las sirenas llevan al muchacho a la punta del cerro. De nuevo, se aprecian las dualidades entre el mundo acuático (uku pacha) y el mundo de arriba (hanan pacha). Ambos espacios míticos.

En la sétima secuencia vemos cómo aparece la fertilidad expresada en los frutos que se le presenta al joven. Además del baile y cantos y el acogimiento en una nueva socialidad.

En la última secuencia, vemos cómo amaina el encanto de estas sirenas y el joven despierta en una cueva con helechos (ambos elementos también cercanos al mundo acuático) y se da cuenta que ha estado equivocado y su vida corre peligro. Por eso huye de ahí.

En el relato observamos las normas que rigen la pervivencia del ayllu, de la sociedad andina. La necesidad del yanantin y del no alejarse del espacio social, que representa además, no alejarse de las normas culturales. Cuando uno está solo es más fácil caer en las seducciones de las sirenas que alteran pero a la vez ordenan el espacio social. 


\section{LA CHIRENA}

\section{Nurubé Norberto Fernández}

La chirena ${ }^{9}$ es lindísima. Su cuerpo es de puro oro. Los turistas de Colombia la vieron con su aparato de ver. Tiene una capa, una piel, que se muda. Cuando llega a casa se cambia, ya no aparece como chirena, sino como ser humano. Tiene todo a su pie, su oreja, sus ojos, su nariz, todo como humano. Los abuelos contaban que le veían a cada rato, cuando el tiempo de la luna llena, no como ahora... Si es mujer, le lleva a los hombres adentro del agua para que sean su marido; al primer hijo de mi hijo le llevaron cuando estaba nadando, cuando era chiquito. Le hacen crecer para ser su esposo. También hay la chirena hombre que se lleva a las mujeres. Esas personas que llevaron ya nunca regresan, se quedan a vivir allá para siempre. Les llevan abajo porque tienen la ciudad allá. La ciudad es como Lima o como Leticia o como Iquitos. Hay mucha gente, pero puro de ellos. Allí viven los bufeos, también son personas, son gringos o son hombres morenos.

Adentro no falta nada: hay luz, la máquina; todo tienen grabadora, música- como en Leticia. Cantan puro huayno. Tienen la taricaya, la charapa, los lagartos, la boa, los pescados, todo lo que vive en el agua. Ellos aumentan los pescados.

La chirena se pone en el río, en las cochas, en la playa. Es como una señora turista, gringa, pero la mano no tiene, está dentro. Es linda, linda; en mi sueño yo la miré una vez. 


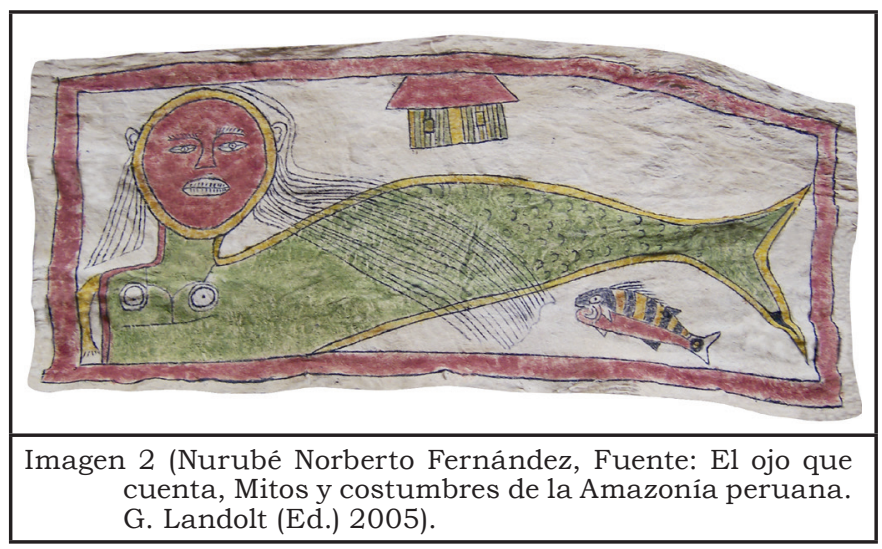

En el relato observamos una descripción de la sirena que conjuga la belleza propia de este ser con su corporalidad cubierta de oro, en un simil con el mito de El Dorado que propició la imaginación y la ambición de los conquistadores y se ha resemantizado hasta la actualidad. La naturaleza dorada de la sirena amazónica le provee entonces de un aura mitica que solo puede ser apreciada por los turistas colombianos (probablemente hay una relación entre el oro mítico de los Yacuruna con el oro proveniente del narcotráfico); así, ellos la pueden observar. Pero también vemos la presencia de la oralidad amazónica en el cambio de piel, como la serpiente, o mejor dicho, como la Yacumama, la madre del agua. Cuando se transforma en humano se hace visible la noción del perspectivismo indígena y esta relación íntima entre los seres del bosque, donde no hay distinción entre humanos y no-humanos. Pero esta sirena ya no la pueden ver los jóvenes de ahora. Han perdido esta capacidad de observarla. Ya no tienen esta relación cercana con la naturaleza, la modernidad no los deja ver ni oír. El narrador se vuelve en un narrador-testigo que relata lo sucedido con su hijo. Es interesante cómo el narrador le da una categoría andró- 
gena a la sirena - a veces es mujer y otras hombres-, diferente a otros relatos en que el ser mítico masculino de los Yacuruna es el bufeo. Aquí hay una predominancia de la sirena, como ser mítico que traspola todo tipo de sustancialidad (como se menciona en el perspectivismo).

El relato tiene un sino fatalista, los que son raptados por la sirena no regresan, se quedan a vivir en el mundo de los Yacuruna, en ciudades tan grande como Lima o Leticia. Es decir, el peligro de la sirena es similar al extravío del mito griego, y el peligro es el desarraigo, el no saber regresar a la comunidad. Este peligro se debe a que en esas ciudades acuáticas — simbolos de la amenazante modernidad - tienen todo, especialmente lo que no poseen en la comunidad: luz eléctrica, máquinas, grabadora (símbolo de poder y de conocimiento: ahí el antropólogo guarda las palabras y testimonios de los antiguos)

Pero además hay dos elementos adicionales y ambivalentes. El primero es que en esas ciudades se canta puro huayno. Es decir, hay una cultura otra que se vuelve hegemónica10; pero también se observan a seres del agua que tienen una connotación chamánica, son espíritus protectores en los espacios entre mundos, que permiten la comunicación entre las diferentes especies vivientes del bosque.

El narrador termina enfatizando la presencia y naturaleza foránea de la chirena pero también da cuenta de su ser mítico al señalar que le falta una mano. Sabemos que hay otros personajes míticos como el chullachaqui que se le reconoce por los pies deformes. El narrador finaliza que ha visto a la sirena en sueños, es decir que no ha sido una percepción onírica (según la lógica occidental, sino una noción perspectivista indígena). Como se conoce, en el pensamiento indígena amazónico los sueños son considerados como un elemento relevante y direccional de lo que llamamos realidad.

Finalmente, como podemos observar, hay una disonancia narrativa entre el texto y la imagen elaborada por el autor. En 
la imagen se puede percibir más los elementos tradicionales de este personaje.

\section{Conclusiones}

- A pesar de ser dos sistemas literarios distintos, en los Andes y Amazonía hay algunos elementos convergentes en los relatos orales que permiten apreciar una serie de préstamos e interacciones culturales.

- En los relatos analizados vemos algunos tópicos comunes como la belleza de la sirena, el entorno mítico que rodea a este ser mítico. En el relato andino vemos que hay una subversión ante la amenaza de este personaje, pero en el amazónico hay una suerte de fatalidad encarnada.

- El análisis comparativo de los relatos orales vigentes en los Andes y la Amazonía - como el de la sirena- enriquecen nuestra comprensión sobre las nuevas formas discursivas orales, las dinámicas de cambio y su relación con el contexto actual.

\section{Nota}

1 J. C. Tello estudia la iconografía andina a partir del análisis de algunos relatos orales de la región amazónica.

2 Es en la década de los 40, con ocasión de los 400 años del "descubrimiento del Amazonas" en que la Amazonía tiene un papel protagónico durante 1943. Ese año se desarrolla la exposición amazónica, organizada por Raúl Porras Barrenechea y Jorge Puccinelli. Además de la famosa exposición se realizaron concursos de cuentos y esculturas sobre la Amazonía, pero sin tener en cuenta los vínculos con los Andes, como si fuesen dos zonas completamente separadas.

3 A nuestro parecer, algunos pueblos amazónicos, sobre todo aquellos más cercanos al área andina, formaban parte de las sociedades que en palabras de Murra, querían tener acceso al control de los pisos verticales.

4 Los Yanesha son un pueblo de la familia Arawak y habitan la selva alta de Junín y Pasco, colindante con la sierra de Lima.

5 Este artículo es una ampliación de un texto anterior (1999) publicado en la Revista de Ciencias Sociales de la UNMSM. 
6 A raíz de la lectura de este sugerente artículo, nos parece interesante abordar un análisis comparativo de algunas crónicas coloniales. Podríamos apreciar las interacciones discursivas y culturales entre las sociedades andinas y amazónicas.

7 Revilla señala que: “Teresa Gisbert nos recuerda que Ludovico Bertonio dejó registrado un dato revelador: "Quesintuu, Umantuu. Son dos hermanas con quien pecó Tunnupa, según se cuenta en las fábulas de los indios". Luego añade: "Quesi Chaulla. Pescado que llaman boga [...] Quesintuu. Otra especie de boga" (Bertonio, 1998 [1612], p.291). Existen dos tipos de boga particulares a la fauna acuática del Lago Titicaca identificada con aquellos nombres. Esto deja creer que las supuestas hermanas eran seres acuáticos semejantes a peces, y que estaban vinculadas al Lago. Bertonio no dice más, y en definitiva nos lleva a considerar una faceta mítica de la memoria andina" (2012, p.137).

8 Hay que señalar que desde la esfera del arte se encuentra la presencia de la sirena en los espacios costeños, andinos y amazónicos. En la exposición "Esplendor de sirenas, música y seducción en las aguas del Perú" bajo la curaduría de Gabriela Germaná, Lala Rebaza y María Eugenia Yllia, realizada en marzo-abril de 2013 se detalla las trayectorias culturales y heterogéneas de este personaje mítico.

9 Según Chirif, en el castellano regional amazónico se encuentran fonemas marginales provenientes del quechua. Chirif resalta que este fonema "cumple la función de apropiarse de palabras foráneas...y de endulzarlas al oído del oyente" (2016, p.26) creemos que el uso de chirena en lugar de sirena cumple esta función.

10 La presencia del huayno se debe a las migraciones andinas recientes en esa zona. Entre ellas los Israelitas del Nuevo Pacto Universal.

\section{Referencias bibliográficas}

Berrocal, C. (2009). Cuentos pintados del Perú. Lima: Fondo Editorial del Congreso de la República.

Chaumeil, J.P (2011). Khipu: ¿Conexiones andino amazónicas? pp. 295-322 En: Chaumeil J.P., Espinosa O. y M. Cornejo Chaparro (eds.) Por donde hay soplo. Estudios amazónicos en los países andinos. Lima: IFEA-PUCP-CAAAP.

Chase Smith, R. (2011). ¿Un sustento arawak en los Andes centrales? La historia oral y el espacio histórico cultural yánesha pp. 219-254. En: Chaumeil J.P., Espinosa O. y M. Cornejo Chaparro (eds.) Por donde hay soplo. Estudios amazónicos en los paises andinos. Lima: IFEA-PUCP-CAAAP. 
Chirif, A. (2016). Diccionario Amazónico. Voces del castellano de la selva del Perú. Lima: Lluvia Editores-CAAAP.

Fernández, N. (2005). La chirena. En Gredna Landolt (ed.): El ojo que cuenta. Mitos y costumbres de la Amazonía peruana. Lima: Ikam.

Gisbert, T. (2012). El paraíso de los pájaros parlantes. La imagen del otro en la cultura andina. ( $3^{\circ}$ edic.). La Paz: Plural Editores.

Godenzzi J.C. y N. Beauclair (2017). Literatura oral en los Andes y la Amazonía pp. 405-430 en: Literaturas orales y primeros textos coloniales J.C. Godenzzi y C. Garatea, (coords,) Historia de las literaturas en el Perú Tomo I R. Chang Rodríguez y M. Velázquez Castro, directores generales. Lima: PUCP Casa de la Literatura.

Espino, G. (comp.) (2003). Tradición oral, culturas peruanas -una invitación al debate- Lima: UNMSM.

Landeo, P. (2010). Categorias andinas para una aproximación al Willakuy Umallanchikpi Kaqkuna (Seres imaginarios del mundo andino). Tesis para optar el grado de Magíster en Literatura Peruana y Latinoamericana. Lima: UNMSM. (https:// unmsm.ent.sirsi.net/client/es_ES/all_libs/search/detailnonmodal/ent:\$002f\$002fSD_ILS\$002fO\$002fSD_ILS:65710/ one?qu=tesis+pablo+landeo).

Mancosu, P. (2013). Fluctuaciones míticas: las sirenas de Gamaliel Churata en: CON TEXTOS, revista Crítica de Literatura. Lima. Año 4, n4. Pp. 103-120.

Mariátegui, J.C. (1928). 7 ensayos de interpretación de la realidad peruana. Lima: El Comercio (2005).

Ortiz Rescaniere, A. (1985). Símbolos y ritos andinos: un intento de comparación con el área vecina amazónica. Anthropologica, 3(3), 61-85. Recuperado a partir de http://revistas.pucp.edu. pe/index.php/anthropologica/article/view/802

Pizarro, A. (2009). Amazonía: el río tiene voces. México: F.C.E.

Pratt, M.L. (2010). Ojos imperiales. Literaturas de viajes y transculturación. México: F.C.E. 
Regan, J. (2011a). Una comparación entre algunos íconos mochicas y mitos jíbaros. pp. 255-270. En: Chaumeil J. P., Espinosa O. y M. Cornejo Chaparro (eds.) Por donde hay soplo. Estudios amazónicos en los países andinos. Lima: IFEA-PUCPCAAAP.

Regan, J. (2011b) Hacia la tierra sin mal. La religión del pueblo en la Amazonía ( $3^{\circ}$ ed.). Lima: CAAAP-CETA.

Revilla, P. (2012). Quesintuu y Umantuu: Sirenas y memoria andina en: RUNA XXXIII (2) pp. 133-155.

Rostorowski, M. (1992). Pachacamac y el Señor de los Milagros. Lima: Instituto de Estudios Peruanos.

Tello J.C. (1923). Wiracocha, Inca vol I n¹: 93-313. Lima: Museo de Arqueología de la Universidad Nacional Mayor de San Marcos.

Viveiros de Castro, E. (2007). La selva de cristal: notas sobre la ontología de los espíritus amazónicos en: Amazonía Peruana $\mathrm{n}^{\circ} 30 \mathrm{pp} 85-110$. 